\title{
Sosyal Medya Kullanımı ile Sosyal Medya Bağımlılık Düzeylerinin Belirlenmesine Yönelik Bir Araştırma: Ege Üniversitesi Örneği
}

Hidaye Aydan (Sillkü) Bilgilier (Dr. Öğr. Üyesi) Ege Üniversitesi İletişim Fakültesi hidaye.aydan.bilgilier@ege.edu.tr

Başvuru Tarihi: 03.05.2018

Yayına Kabul Tarihi: 01.06.2018

Yayınlanma Tarihi: 30.07.2018

Öz

Bu araştırmanın amacı, Ege Üniversitesi İletişim Fakültesi Halkla İlişsiler ve Tanıtım Bölümünde okuyan öğrencilerinin sosyal medya kullanım alışkanlıkları ile sosyal medya bağımlılık düzeylerinin ne yönde olduğunu belirlemektedir.

Araștırma örneklemi; İletişim Fakültesi Halkla İlişkiler ve Tanıtım Bölümünde 1. ve 2. Öğretimde okuyan lisans ve lisansüstü öğrencilerden olmak üzere toplam 436 öğrenciden oluşmaktadır ( $\mathrm{n}=436)$. Araștırmada Şahin ve Korkmaz (2011) tarafından geliştirilen "İnternet Bağımlılığı Ölçeği" (IBÖ) ile kişisel bilgi formu uygulanmıştır. Araștırma verilerine; yüzde (\%), frekans (f), Mann Whitney U-testi ve Kruskal Wallis H-testi uygulanmıștır.

Araştırma bulguları, İletişim Fakültesi Halkla İlişkiler ve Tanıtım bölümü lisans ve lisansüstü öğrencilerin sosyal medya bağımlılığının; cinsiyet ve sosyal medyada aktif kalınan süre arasında anlamlı bir ilişki olduğunu ortaya koymuştur. Sosyal medya bağımlılığının öğrencilerin kontrol kaybı boyutunda kızlarda daha fazla olduğu ve gençlerin sosyal medyada aktif oldukları süre ile medya bağımlılıklarının paralel olarak arttığı söylenebilir.

Anahtar Kelimeler: Halkla İlişkiler ve Tanıtım Bölümü Öğrencileri, Sosyal Medya Kullanım Alışkanlıkları, Sosyal Medya Bağımlılığı. 


\title{
A Study on Determining the Levels of Social Media Usage and Addiction: The Case of Ege University
}

\author{
Hidaye Aydan (Silkü) Bilgilier (Asst. Prof. Dr.) \\ Ege University Faculty of Communication \\ hidaye.aydan.bilgilier@ege.edu.tr
}

Date Received: 03.05.2018

Date Accepted: 01.06.2018

Date Published: 30.07.2018

\section{Abstract}

The aim of this study is to determine the levels of social media usage habits and addiction of the public relations and promotion students of Ege University Faculty of Communication.

The sampling of research of this study is composed of 436 undergraduate and gradute students at primary (daytime) and secondory (evening) programs of the Department of Public Relations and Promotion, of the Faculty of Communication $(\mathrm{n}=436)$. In conducting the research, the Internet Addiction Scale, developed by Şahin and Korkmaz in 2011, and a personal questionaire have been used. The data obtained have been assessed in accordance with the percentage, frequency, Mann Whitney U-test, and Krustel Wallis H-tests.

The reseach findings have revealed that there is a meaningful correlation between the social media addiction and the gender and the active participation duration of the public relations and promotion undergradute and gradute students of the Faculty of Communication.

Accordingly, it can also be stated that the level of the students' losing their control against the social media addiction is higher in girls, and there is a parallel increase between the duration of the youngsters' active participation in social media and their addiction to it.

Keywords: The Public Relations and Promotion Students, Social Media Usage Habits, Social Media Addiction. 


\section{Giriş}

Sosyal medya, amaçları Web 2.0 ile etkileşimli bir bilgi alışverişi yapmak, ilgilenilen konulara yönelik olarak ayni fikirlerdeki farklı insanlarla tanışmak olan kişilerin sosyal ağ siteleri ile internet ortamında toplanmasıyla ortaya çıkmıștır (Kuyucu, 2014,64).Diğerbirifadeyle sosyal medya, kullanıcıları tekyönlübilgi paylaşımından, karşılıklı etkileşim ortamına taşıyan, eş zamanlı ve çok yönlü paylaşımlara imkan kılan teknolojik bir medya sistemidir (Özutku ve diğerleri, 2014, 29). Sosyal medya, Web 2.0 uygulamaları tüketiciler ile doğrudan ilişki kurabilmekte ve birtakım süreçleri bu uygulamalarda sürdürebilmekte ve yönetebilmektedir. Bunların içinde yazmak, bağlantı paylaşmak ve sosyal ağ kurmak vs. vardır. Profesyoneller, sosyal medya kanallarını ürün tanıtımı, ilgili reklamlar, doğrudan pazarlama, interaktif pazarlama, e-ticaret, satış promosyonları, kişisel satış, duyurum ve halkla ilişkiler amaçlı kullanabilmektedirler. Web 2.0 teknolojileri aynı zamanda viral pazarlamaya imkan sağlar, kullanıcıların fikirleri ve paylaşımları hakkında bilgi elde edilmesine olanak tanımaktadır. Bu yeni seçenek, Web 2.0'ın özelliği olup kullanıcılar bu mecralarda kontrolü kendi ellerinde bulundurmaktadır (Thackeray ve diğerleri, 2008, 338).

Sosyal medyanın bu interaktivite özelliği ile kişiler pasiflikten çıkarak, kendi sözlerini söyleyerek, sorular sorarak birbirleriyle iletişime geçmekte ve dinamik bir platform oluşturulmaktadırlar (Sevinç, 2015, 87). Sosyal medya mecraları anlık mesaj gönderimini, blog, wikiler ve çeşitli forum sitelerini mümkün kılan uygulamalara imkan vermektedir (Sutton, Palen ve Shklovski, 2008, 2). Web 2.0 içerik paylaşımı, bağlanma, iş birliği yapma ve çeşitli jenerasyonlarda kullanıcıların içerik üretme imkanını beraberinde getirmiștir. Web 2.0 yani sosyal medya uygulamaları, kullanıcılara hem üretme hem de bilgiyi yönetmeyi sağlamaktadır. Bu mecralarda amaçlara uygun olarak sayısız uygulamalar mevcuttur. Örneğin bloglar aracılı̆̆ıyla kullanıcılar fikirlerini ve düşüncelerini, bir konu hakkında bilgilerini paylaşma yoluna gidebilmektedirler. Video paylaşım siteleri komik, eğlendirici ve bilgilendirici vs. içerikleri paylaşmayı sağlayabilmektedir (Thackeray ve diğerleri, 2008, 339).

Bireyler artan bir oranda sosyal medya platformlarını kullanmaktadırlar. Bunlar içinde Facebook ve Twitter da oldukça popüler bir durumdadır. Bu sosyal medya kanallarında bağlantılarını, fikir ve görüşlerini bildirebilmekte ve bunları paylaşabilmektedirler. Sosyal medya platformlarında günlük aktivitelerini, yeni içeriklerini ve neler olup bittiğini paylaşabilmektedirler. $\mathrm{Bu}$ mecralarda anı yakalayabilmekte, bireysel düşüncelerini belirtip iletişim kurabilmekte ve sosyalleşebilmektedirler (Choudhury ve diğerleri, 2013, 1). Sosyal medya araçları (Facebook, Myspace, LinkedIn, Twitter, vs.) eşsiz bir biçimde kullanıcılarının birbirleriyle arkadaş olmasına, birbirlerinin bağlantılarını paylaşmasına vb. birçok etkinliğe izin vermektedir (Hampton ve diğerleri, 2011, 8). Sosyal ağlar birçok yaygın özelliğe sahiptir. Bu özellikler; bir arkadaş listesi oluşturmayı, prestijini göstermeyi, diğer kullanıcılar ile etkileşmeyi, fikir ve düşünce paylaşımını, bir başka kullanıcının bağlantısını beğenmeyi, özel mesajlar göndermeyi içermektedir. Sosyal ağlar, insanların daha çok arkadaş edinmesini, aile üyelerine ulaşmassını, iş arkadaşlarıyla bağlantı kurmayı ve diğer birçok tanıdık kişiler ile ortak bir alan oluşturmayı sağlamaktadır (Hampton ve diğerleri, 2011, 14-22). Sosyal medya forumlar, bloglar, fotoğraflar, videolar, profiller ve dahası çeşitli bağlantıların bir web ortamına yüklenmesi durumudur. Sosyal medya herhangi bir beceri ya da kod bilgisi 
gerektirmeden insanların kolay bir şekilde postlar oluşturmasına ve paylaşımlar yapılmasına izin veren yapılardır. Diğer bir deyişle; sosyal medya bilgiyi türlü şekillerde çeşitli ağlarda paylaştığımız ve bu ağları kullandığımız web servisleridir. Popüler sosyal medya platformları arasında Facebook, LinkedIn, Plaxo, MySpace gibi araçlar yer almaktadır (Elley ve Tilley, 2009, 78-81).

Sosyalağlararacılığıylakullanıcılarkendilerineözgübirkişiselbilgilerdenoluşan profil oluşturabilmekte ve diğer arkadaşlarıyla bunu paylaşabilmektedir. Oluşturdukları bu profiller özellikle etkileşimlidir ve kullanıcılar bunlar hakkında yorum yapabilmekte ya da diğer arkadaşları ile paylaşabilmektedirler. Bu profiller tamamen kişiye özel bir şekilde de oluşturulabilir ve bunun kontrolü ve değiștirilmesi kullanıcının kendisine kalmıștır ve tüm bunları profil sayfasında sergileyebilmektedir. Bazı sosyal ağlarda ağ sayfaları da oluşturulabilmektedir. Eğer bu sayfaların yöneticisi ya da kurucusu iseniz, birtakım değişiklikler ya da düzeltmeler yapabilir ve ne gösterileceğiyle ile ilgili tüm kontrolleri kendiniz gerçekleştirebilirsiniz. Bir sosyal ağa girdiğiniz zaman, kişisel profilinizi oluşturabilirsiniz. Bu profiller; kullanıcı adı, yer bilgisi, doğum tarihi, statü, iş bilgileri, cinsiyet, dini bilgiler, hayat tarzı, favorileri içermektedir (Tamar, $2009,150)$. Türkiye ve dünyada yapılmış araştırmalarda, kişilerin medya içeriklerini izleyerek ya da takip ederek elde ettikleri doyumlar şu şekilde sıralanmaktadır: eğlence, bilgilenme, boş zamanı geçirme, rahatlama/stresten uzaklaşma, sosyalleşme (Akçay, 2011, 142). Kuss ve Griffiths (2011)'in sosyal ağlar ve bu ağlara bağımlılık hakkında yapmış oldukları bir araştırmada üzerinde durdukları en önemli nokta "sosyalleşme" isteği yönündedir. Kuşay (2013)'a göre sosyalleşme ya da var olma içgüdüsü ile gelişen bağımlılık, kullanıcılarda mutluluk, beklenti, haz, istek sonucu gelişen bir başarı gibi motivasyon unsurlarını tetiklemektedir.

Günümüzde artık herkes sosyal medyada paylaşımda bulunduğu ve aktif kullanıcısı olduğu sanal bir veya birden fazla siteye üye olarak bu mecralarda yer almaktadır (Babacan, 2015, 55). Kişiler başka kișilerle iletişime girebilmek, kendilerini özgürce ifade edebilmek, eski tanıdıklarına ulaşabilmek ve iletişime girebilmek gibi çeşitli nedenlerle sosyal paylaşım sitelerinde yer almaktadırlar (Kuss ve Griffiths, 2011).

Web 2.0 sosyal medya raporları göstermektedir ki, sosyal medya mecraları genel nüfusta artan bir trend olmuş fakat özellikle genç nüfusta bu daha fazladır (Thackeray ve diğerleri, 2008, 339). Türkiye'de bilgisayar ve internet teknolojilerinin kullanımı; TUİK 2017 Ağustos ayı sonuçlarına göre, bilgisayar ve internet kullanımı 2017 yılında (16-74) yaş grubundaki bireylerde sırasıyla \%56,6 ve $\% 66,8$ oldu. Bu oranlar 2016 yılında sırasıyla \%54,9 ve \%61,2 idi. Hane halkı bilişim teknolojileri kullanım araştırması sonuçlarına göre 2017 yılı Nisan ayında hanelerin \%80,7'si evden internete erişim imkânına sahip oldu. Bu oran 2016 yılının aynı ayında \%76,3 idi. Geniş bant internet erişim imkânına sahip hanelerin oranı 2017 yılı Nisan ayında \%78,3 oldu. Buna göre hanelerin \%40’ı sabit geniş bant bağlantı (ADSL, kablolu İnternet, fiber vb.) ile İnternete erişim sağlarken, \%72,4'ü mobil geniş bant bağlantı ile internete erişim sağladı. Geniș bant internet erişim imkânına sahip hanelerin oranı önceki yıl \%73,1'di (TUİK, 2017). Bu istatistik sonuçlarına bakıldığında Türkiye'de bilgisayar, internet kullanımının gençler arasında artan oranda yaygın olduğu söylenebilir. Türkiye'de sosyal medya kullanıcılarının büyük bir kısmını oluşturan genç-yetişkin grup mobil iletişim ile sosyalleşmektedir (Özutku ve diğerleri, 2014, 38). Gençlerin sosyal bağlarını kuvvetlendirmek için sosyal medyayı kullanmakta oldukları gerçek bir durumdur. 
Ancak sosyal medya sağlıklı yüz yüze iletişimi sağlayamıyorsa, sosyal medyanın bir önemi yoktur (Alioğlu, 2015, 12).

Günümüzde internetin yoğun kullanımı özellikle dijital çağda doğup büyüyen çocuklarda problem olarak ortaya çıkmaktadır (Seferoğlu ve Yıldız, 2013, 32). Sosyal ağların ihtiyaçlar dışında aşırı ve kontrolsüz bir şekilde kullanılması "dürtü kontrol bozukluğu" (Griffiths, 1999; Young, 1998; Seferoğlu ve Yıldız, 2013, 32) şeklinde ortaya çıkarak özellikle uzun süreçli olarak sosyal medyayı aktif kullanan gençlerde sosyal medya bağımlılığı oluşabileceği șeklinde yorumlanabilir. Bu bağlamda Medya Bağımlılığı kuramı; ilk olarak 1976 yılında Sandra Ball-Rokeach ve Melvin De Fleur tarafından sosyolojik bakış açısıyla ele alınarak iletişim araçları sosyal sistem ve izleyiciler arasındaki ilişkilere odaklanmaktadır. Bu kurama göre, bireyler modern toplumlara dair bilgilendirilmek, yönlendirilmek üzere kitle iletişim araçlarına bağımlı oldukları; bu bağımlılığın, toplumdaki değişim, istikrar ve çatışma derecesiyle kitle iletişim araçlarının bilgi kaynağı olarak merkezi konum ve önem derecesine göre şekillendiğini savunmaktadır. Medya, izleyiciler ve sosyal sistem arasındaki karşılıklı etkileşim ile belirlenen medyanın etkileri, bireylerin ihtiyaç ve beklentileri doğrultusunda bağımlılıklara yol açmaktadır. Kullanımlar, doyumlar yaklaşımı da medya bağımlılığı kuramının gelişmesinde öncülük etmiştir. Sosyal medya ortamları, bireylere hem kişisel hem de sosyal etkileşim imkanı tanımakta ve bireysel ve sosyal düzeyde davranışları yönlendirmede etkili olmaktadır (Işılk ve Topbaş, 2015, 320-323). Sosyal medya özellikle ergen kullanıcıların kimlik/benlik olgusunun oluşumunda, eğlence, merak gibi duyguların tatminine yönelik geliştirilen gerçek gibi bir algılanan sanal ortam, sosyal medyadaki farklı uygulamaların etkisiyle sosyal yașamı yönlendirilmektedir. Sosyal medya, erginin davranışlarının yönlendirilmesinde ve eğilimlerinin tespit edilmesinde "farkındalık" yaratma açısından güç kazanmaktadır ve özellikle gençlerin iletişim stratejilerini yakından etkilemektedir (Kuşay, 2013, 136).

Bütün bu sözü edilen gerekçelerden hareketle bu çalışmada; bireysel ve toplumsal süreçte önem arz eden teknoloji ve sosyal medya ile iç içe büyüyen bir kuşak olan üniversite gençlerinin sosyal medya kullanımları ile sosyal medya bağımlılık düzeylerinin araștırılması planlanmıștır. Bu kapsamda, bir örneklem üzerinden durum analizi yapılarak elde edilen bulgular doğrultusunda alanla ilgili araştırma yapacaklara rehberlik edebilecek öneriler sunulması ve benzer çalışmalara katkı sağlanması hedeflenmiştir.

\section{Ege Üniversitesi İletişim Fakültesi Halkla İlişkiler ve Tanıtım Bölümü Öğrencilerinin Sosyal Medya Kullanımı İle Sosyal Medya Bağımlılık Düzeylerinin Analizi}

\section{Araştırmanın Amacı}

Bu araştırmada amaç, Ege Üniversitesi İletişim Fakültesi Halkla İliş̧kiler ve Tanıtım Bölümünde okumakta olan öğrencilerin internet teknolojilerinin bir çıktısı olan sosyal medya kullanım alışkanlıklarını tespit etmek ve sosyal medya bağımlılık düzeylerinin ne yönde olduğunu belirlemektir.

\section{Araştırmanın Konusu ve Önemi}

Bu araştırmayla Ege Üniversitesi İletişim Fakültesi Halkla İlişkiler ve Tanıtım Bölümü öğrencilerinin öncelikle demografik özellikleri genel olarak ortaya konulmuştur. Ardından, öğrencilere yöneltilen sosyal medya kullanım alışkanlıklarına ilişkin sorularla öğrencilerin sosyal medya kullanım alışkanlıkları tespit edilmeye 
çalışılmıştır. Son olarak da, sosyal medyayı kullanan genç kuşak bireylerin bağımlılık düzeylerinin ne yönde olduğu tutum ve davranış ölçeğiyle ölçümlenmeye çalışılmıştır.

\section{Araştırmanın Varsayımları ve Hipotezleri}

- Ege Üniversitesi İletişim Fakültesi Halkla İlişkiler ve Tanıtım Bölümü öğrencilerinin sosyal medya kullanım alışkanlıklarına yönelik ankette yer alan önermeler ile sosyal medya bağımlılık düzeylerini tutum ve davranıșları kapsamında ölçen ölçekte yer alan önermeler, söz konusu amaç dahilinde öğrencilerin durumlarını tespit etmek için yeterlidir.

- Seçilen araştırma yöntemi, araştırmanın amacına, konusuna ve soruların çözümüne uygundur.

- Anket katılımcıları, Ege Üniversitesi İletişim Fakültesi Halkla İlişkiler ve Tanıtım Bölümü öğrencilerinin sosyal medya kullanım alışkanlıkları ile sosyal medya bağımlılık düzeylerini ölçmek için yeterli sayıdadır.

- İnternet/Sosyal medya bağımlılığı ile cinsiyet arasında anlamlı bir ilişki vardır (Hipotez 1) (Tablo 9).

- İnternet/Sosyal medya bağımlılığı ile yaş arasında anlamlı bir ilişki vardır (Hipotez 2) (Tablo 10).

- İnternet/Sosyal medya bağımlılığı ile öğretim türü arasında anlamlı bir ilişki vardır (Hipotez 3) (Tablo 11).

- İnternet/Sosyal medya bağımlılığı ile sınıf arasında anlamlı bir ilişki vardır (Hipotez 4) (Tablo 12).

- İnternet/Sosyal medya bağımlılığı ile gelir arasında anlamlı bir ilişki vardır (Hipotez 5) (Tablo 13).

- Internet/Sosyal medya bağımlılığı ile sosyal medyaya girilen ortam arasında anlamlı bir ilişki vardır (Hipotez 6) (Tablo 14).

- İnternet/Sosyal medya bağımlılığı ile sosyal medyada aktif olunan süre arasında anlamlı bir ilişki vardır (Hipotez 7) (Tablo 15-Tablo 25).

- İnternet/Sosyal medya bağımlılığı ile sosyal medyayı kullandığı yıl süresi arasında anlamlı bir ilişki vardır (Hipotez 8) (Tablo 26).

\section{Araştırmanın Kapsamı ve Sınırlılıkları}

- Araştırma bulguları anketin yapıldığı bölümdeki öğrencilerin, anketin yapıldığı tarihteki sosyal medyaya ve sosyal medya bağımlılığına ilişkin algılarını yansitmaktadir.

- Anketle toplanan verilerin güvenirliliği ve geçerliliği veri toplamada kullanılan bu tekniğin özellikleri ile sinırlıdır.

- Zamanın kısıtlı olması araştırmayı sınırlandırmaktadır.

- Maliyetin fazla olması nedeniyle araştırma sınırlandırılmıştır.

- Araştırma örneklemi Ege Üniversitesi İletişim Fakültesi Halkla İlişkiler ve Tanıtım bölümünde birinci ve ikinci öğretimde okuyan lisans ve lisansüstü toplam 436 öğrenci ile sınırlıdır.

\section{Araştırma Yöntemi}

Ege Üniversitesi İletişim Fakültesi Halkla İlişkiler ve Tanıtım bölümünde birinci ve ikinci öğretimde eğitim gören lisans düzeyi öğrencileri ile lisansüstü öğrencilerin sosyal medya kullanım alışkanlıkları ile sosyal medya bağımlılık düzeylerini ölçmeye yönelik yapılan bu çalışmada basit rastlantısal örneklem yöntemi esas alınmıştır. Bu amaç doğrultusunda Ege Üniversitesi İletişim Fakültesi Halkla İlişkiler ve Tanıtım 
Bölümü birinci ve ikinci öğretim 1,2,3,4. sınıf ile lisansüstü düzeyde öğrenim gören 498 öğrenci çalışma evreni olarak seçilmiştir.

Ege Üniversitesi İletişim Fakültesi Halkla İlişkiler ve Tanıtım Bölümünden 436 kişi örneklem olarak seçilmiştir. Örneklemi oluşturan gruplara anket yöntemi ile ulaşılmaya çalıșılmıştır ve anket soruları araştırmacı tarafından yüz yüze gerekli açıklamalar yapıldıktan sonra ders saatleri içerisinde uygulanmıştır.

\section{Araştırmanın Evreni ve Örneklemi}

Araştırmanın evrenini Ege Üniversitesi İletişim Fakültesi Halkla İlişkiler ve Tanıtım Bölümünde 1. ve 2. öğretimde okuyan lisans ve lisansüstü öğrencilerden 498 kişi oluşturmaktadır. Araştırmanın örneklemi basit rastlantısal örneklem yöntemiyle seçilmiştir. Toplamda 498 anket cevaplarından 2 tanesi hatalı olması sebebiyle iptal edilmiş, 60 adet cevaplanmamış ya da derse katılımları olmadığından iptal edilmiştir. Sonuç olarak 436 kişinin anketi örneklem kapsamına dahil edilmiştir.

\section{Veri Toplama Aracı}

Araştırmada konu, amaç ve sinırlılıklar göz önünde tutularak veri toplama tekniklerinden anketin (soru kağıdı) seçilmesi uygun görülmüştür. "İnternet Bağımlılığı Ölçeği (İBÖ)” isimli, Şahin ve Korkmaz tarafından 2011 yılında geliştirilen ölçek kullanılmıştır. Bireylerin internet bağımlılık düzeylerini ölçmeye yönelik bu ölçek 19 sorudan oluşmaktadır. Sorular, 1=Hiçbir zaman, 5=Her zaman olarak örneklem birimlerine yansıtılmıştır.

Ölçeğin bütününden toplam puan olarak en düşük 19, en yüksek 95 puan alınabilir. Ölçekten alınan puanlar yükseldikçe bağımlılık düzeyinin yükseldiği kabul edilmektedir. Ölçeğin üç alt boyutu vardır: birincisi "kontrol kaybı", ikincisi "daha fazla online kalma isteği” ve üçüncüsü ise "sosyal ilişkilerde olumsuzluk" tur.

Kontrol kaybı, bireylerin interneti /sosyal medyayı ölçüsüz kullanması ve bu tutumundan bir türlü vazgeçmemesi neticesinde çeşitli sorunlar yaşamasını ifade eder. Daha fazla online kalma isteği, internet/sosyal medya kullanımında harcanan zamanı gösterir ve internet/sosyal medya kullanımında aşırılığın başlangıç dönemiyle karşılaştırıldığında açıkça daha da yükselmiş olduğunu ortaya koyar. Sosyal ilişkilerde olumsuzluk ise, aşırı internet/sosyal medya kullanımı nedeniyle insanlar arasındaki ilişkilerde meydana gelen sorunları ifade eder (Şahin ve Korkmaz, 2011, 111).

\section{Veri Analizi ve Verilerin Çözümlenmesi}

Güvenirlik analizi SPSS istatistik paket programı "Reliabity Analysis" ile gerçekleştirilmiştir. Cronbach Alpha iç tutarlılık yöntemiyle belirlenen güvenirlik katsayısı (.944) olarak çıkmıştır. Araştırma kapsamında 436 kişiye uygulanan anketin güvenirlik katsayısı (.871) (Tablo 9) iken, alt boyutlarından birincisi "kontrol kaybı" güvenirlilik katsayısı (.876) (Tablo 10), ikincisi, "Daha fazla online kalma isteği" güvenilirlik katsayısı (.935) (Tablo 11), üçüncü alt boyut olan "sosyal ilişkilerde olumsuzluk" güvenilirlik katsayısı (.935) (Tablo 12) olarak çıkmıștır. Bu değerler, verilerin genel olarak faktör analizine uygun olduğunu göstermektedir.

\section{Araştırma Bulguları ve Değerlendirilmesi}

Aşağıdaki anket sonuçlarına ilişkin veriler; toplam 438 kişiye uygulanan anket sorularından elde edilen 436 kişinin yanıtlarını kapsamaktadır. 


\section{Demografik Bulgular}

Tablo 1: Cinsiyete İlişkin Bulgular

\begin{tabular}{|l|l|c|c|}
\hline \multicolumn{2}{|c|}{} & Frekans (f) & Yüzde (\%) \\
\hline \multirow{3}{*}{ Cinsiyet } & Kadın & 245 & 56,2 \\
\cline { 2 - 4 } & Erkek & 191 & 43,8 \\
\cline { 2 - 4 } & Toplam & 436 & 100 \\
\hline
\end{tabular}

Demografik özelliklerde cinsiyete ilişkin bulgular Tablo 1'de gösterilmiştir. Tablodaki veriler göz önüne alındığında araştırmaya katılanların \% 56,2'si kadın (n=245), \% 43,8'i (n=191) erkek katılımcıdır.

Tablo 2: Yaş Değişkenine İlişkin Bulgular

\begin{tabular}{|c|l|c|c|}
\hline \multicolumn{2}{|c|}{} & Frekans (f) & Yüzde (\%) \\
\hline \multirow{4}{*}{} & $18-21$ & 185 & 42,4 \\
\cline { 2 - 4 } & $22-25$ & 210 & 48,2 \\
\cline { 2 - 4 } Yaş & $26-29$ & 22 & 5,0 \\
\cline { 2 - 4 } & 30 ve üzeri & 19 & 4,4 \\
\cline { 2 - 4 } & Toplam & 436 & 100 \\
\hline
\end{tabular}

Demografik özelliklerde yaş değișkenine ilişkin bulgular Tablo 2'de gösterilmiștir. Tablodaki veriler göz önüne alındığında araştırmaya katılanların \% 42,4'ü (18-21) yaş ( $n=185), \% 48,2$ 'si (22-25) yaş (n=210), \%5'i (26-29) yaş (n=22), \%4,4'ü (30 ve üzeri) yaş (n=19) aralığında oldukları gözlenmektedir.

Tablo 3: Öğretim Türü Değişkenine İlişkin Bulgular

\begin{tabular}{|l|l|c|c|}
\hline \multicolumn{2}{|c|}{} & Frekans (f) & Yüzde (\%) \\
\hline \multirow{3}{*}{ Öğretim Türü } & Birinci Öğretim & 292 & 67,0 \\
\cline { 2 - 4 } & İkinci Öğretim & 144 & 33,0 \\
\cline { 2 - 4 } & Toplam & 436 & 100 \\
\hline
\end{tabular}

Demografik özelliklerde öğretim türü değişkenine ilişkin bulgular Tablo 3'te gösterilmiştir. Tablodaki veriler göz önüne alındığında araştırmaya katılanların \% 67'si birinci öğretimde $(n=292), \% 33$ 'ü ikinci öğretimde $(n=144)$ eğitim gördükleri gözlenmektedir.

Tablo 4: Sınıf Değişkenine İlişskin Bulgular

\begin{tabular}{|l|l|c|c|}
\hline \multicolumn{2}{|l}{} & Frekans (f) & Yüzde (\%) \\
\hline \multirow{4}{*}{ Sinıf } & 1 & 41 & 7,0 \\
\cline { 2 - 4 } & 2 & 76 & 17,4 \\
\cline { 2 - 4 } & 3 & 134 & 30,7 \\
\cline { 2 - 4 } & 4 & 118 & 27,1 \\
\cline { 2 - 4 } & Lisansüstü & 34 & 7,8 \\
\cline { 2 - 4 } & Toplam & 436 & 100 \\
\hline
\end{tabular}

Demografik özelliklerde sınıf değişkenine ilişkin bulgular Tablo 4'te gösterilmiştir. Tablodaki veriler göz önüne alındığında araştırmaya katılanların \% 17'si birinci sınıfta (n=74), \%17,4'ü ikinci sinıfta ( $n=76), \% 30,7$ 'si üçünü sınıfta (n=134), \%27,1'i dördüncü sinıfta (n=118), \%7,8’i lisansüstü (yüksek lisans/doktora) eğitimde $(n=34)$ araştırmaya katıldıkları gözlenmektedir. 
Tablo 5: Gelir Değișkenine İlişskin Bulgular

\begin{tabular}{|l|l|c|c|}
\hline \multicolumn{2}{|c|}{} & Frekans (f) & Yüzde (\%) \\
\hline \multirow{4}{*}{ Gelir } & 500 TL'nin altı & 104 & 23,9 \\
\cline { 2 - 4 } & $501-1000$ TL arası & 194 & 44,5 \\
\cline { 2 - 4 } & 1001 TL ve üzeri & 138 & 31,7 \\
\cline { 2 - 4 } & Toplam & 436 & 100 \\
\hline
\end{tabular}

Demografik özelliklerde gelir değişkenine ilişkin bulgular Tablo 5'te gösterilmiștir. Tablodaki veriler göz önüne alındığında araștırmaya katılanların \% 23,9'u (500 TL'nin altı) gelir grubunda ( $\mathrm{n}=104), \% 44,5$ 'i $(501-1000$ TL arası) gelir grubunda $(n=194)$, \%31,7’si (1001 TL ve üzeri) gelir grubunda ( $\mathrm{n=138)}$ yer aldıkları saptanmıştır.

\section{Sosyal Medya Kullanımına İlişkin Demografik Özellikler}

Tablo 6: Sosyal Medyaya Girilen Ortama İlişkin Bulgular

\begin{tabular}{|l|l|c|c|}
\hline \multicolumn{2}{|c|}{} & Frekans (f) & Yüzde (\%) \\
\hline \multirow{4}{*}{$\begin{array}{l}\text { Sosyal medyaya } \\
\text { girdiğiniz ortam }\end{array}$} & Ev/Yurt & 394 & 90,4 \\
\cline { 2 - 4 } & Okul & 7 & 1,6 \\
\cline { 2 - 4 } & Internet Cafe & 0 & 0 \\
\cline { 2 - 4 } & Diğer & 35 & 8,0 \\
\cline { 2 - 4 } & Toplam & 436 & 100 \\
\hline
\end{tabular}

Demografik özelliklerde sosyal medyaya girilen ortama ilişkin bulgular Tablo 6'da gösterilmiştir. Tablodaki veriler göz önüne alındığında araştırmaya katılanların \% $90,4$ 'ü ev/yurt ( $n=394), \% 1,6$ 'sı okul $(n=7), \% 8$ 'i diğer $(n=35)$ ortamlarından sosyal medyaya girdikleri ortaya koyulmuştur. Bunun yanında, internet cafe ortamının sosyal medyaya bağlanma konusunda bu örneklem birimi tarafından tercih edilmediği görülmüştür.

Tablo 7: Gün İçinde Sosyal Medyada Aktif Olunan Süreye İlişskin Bulgular

\begin{tabular}{|l|l|c|c|}
\hline \multicolumn{2}{|l|}{} & Frekans (f) & Yüzde (\%) \\
\hline \multirow{4}{*}{$\begin{array}{l}\text { Sosyal medyada aktif } \\
\text { olduğunuz süre }\end{array}$} & 1 saatten daha az & 66 & 15,1 \\
\cline { 2 - 4 } & 1-3 saat & 210 & 48,2 \\
\cline { 2 - 4 } & $4-6$ saat & 121 & 27,8 \\
\cline { 2 - 4 } & 7 saat ve üzeri & 34 & 7,8 \\
\cline { 2 - 4 } & Diğer & 5 & 1,1 \\
\cline { 2 - 4 } & Toplam & 436 & 100 \\
\hline
\end{tabular}

Demografik özelliklerde gün içerisinde sosyal medyada aktif olunan süreye ilişkin bulgular Tablo 7'de gösterilmiştir. Tablodaki veriler göz önüne alındığında araştırmaya katılanların \% 15,1'i (1 saatten daha az) (n=66), \% 48,2'si (1-3 saat arası) (n=210), \% 27,8'i (4-6 saat arası) (n=121), \% 7,8'i 7 saat ve üzeri $(n=34)$ ve $\% 1,1$ 'i diğer $(n=5)$ zaman dilimleri arasında sosyal medyada aktif oldukları ortaya koyulmuştur. 
Tablo 8: Sosyal Medya Kullanım Yılına İlişsin Bulgular

\begin{tabular}{|l|l|c|c|}
\hline \multicolumn{2}{|c|}{} & Frekans (f) & Yüzde (\%) \\
\hline \multirow{4}{*}{$\begin{array}{l}\text { Kaç yıldır sosyal medya } \\
\text { kullanmaktasınız? }\end{array}$} & 1 yıldan daha az & 5 & 1,1 \\
\cline { 2 - 4 } & $1-3$ yıl & 26 & 6,0 \\
\cline { 2 - 4 } & $4-6$ yıl & 192 & 44,0 \\
\cline { 2 - 4 } & 7 yıldan daha fazla & 203 & 46,6 \\
\cline { 2 - 4 } & Diğer & 10 & 2,3 \\
\cline { 2 - 4 } & Toplam & 436 & 100 \\
\hline
\end{tabular}

Demografik özelliklerde sosyal medya kullanım yılına ilişkin bulgular Tablo 8'de gösterilmiştir. Tablodaki veriler göz önüne alındığında araştırmaya katılanların \% 1,1'i (1 yıldan daha az) (n=5), \%6'sı (1-3 yıl) ( $n=26), \%$ 44'ü (4-6 yll) (n=192), \% 46,6 'sı (7 yıldan daha fazla) $(n=203)$ ve $\% 2,3$ 'ü diğer $(n=10)$ yıl grubunda sosyal medyayı kullandıklarını belirtmişlerdir.

\section{Araştırmanın Güvenirliğine İlişkin Bulgular Sosyal Medya Bağımlılığı Ölçeğinin Güvenirliği}

Araştırma kapsamında 436 kişi üzerinde uygulanan anketin güvenirlik testi SPSS Reliability ile gerçekleştirilmiştir. Cronbach Alpha iç tutarlık yöntemiyle belirlenen güvenirlik skorları $0.944(\mathrm{~N}=19)$ olarak çıkmıştır. Bu doğrultuda uygulanan anket çalışması uygulandığı grup bakımından yüksek güvenilirlik derecesi elde etmiştir.

\section{Sosyal Medya Bağımlılığı Ölçeğinin “Kontrol Kaybı” Bileşeninin Güvenirliği}

Ölçeğin kontrol kaybı boyutunun güvenirlik skoru Cronbach Alpha iç tutarlık yöntemiyle $0.871(\mathrm{~N}=7)$ olarak çıkmıştır. Bu anlamda uygulanan anket çalışması uygulandığı grup bakımından yüksek güvenilirlik derecesi elde etmiştir.

\section{Sosyal Medya Bağımlılığı Ölçeğinin "Daha Fazla Online Kalma İsteği” Bileşeninin Güvenirliği}

Ölçeğin daha fazla online kalma isteği boyutunun güvenirlik skoru Cronbach Alpha iç tutarlık yöntemiyle $0.876(\mathrm{~N}=4)$ olarak çıkmıştır. $\mathrm{Bu}$ anlamda uygulanan anket çalışması uygulandığı grup bakımından yüksek güvenilirlik derecesi elde etmiştir.

\section{Sosyal Medya Bağımlıı̆ğ Öıçeğinin "Sosyal İlişkilerde Olumsuzluk" Bileşeninin Güvenirliği}

Ölçeğin sosyal ilişkilerde olumsuzluk boyutunun güvenirlik skoru Cronbach Alpha iç tutarlık yöntemiyle $0.935(\mathrm{~N}=8)$ olarak çıkmıştır. Bu anlamda uygulanan anket çalışması uygulandığı grup bakımından yüksek güvenilirlik derecesi elde etmiştir.

İnternet teknolojilerinin bir çıktısı olan sosyal medyayı kullanan genç kuşak bireylerinin bağımlılık düzeylerinin ne yönde olduğunun belirlenmesi ve demografik değişkenler açısından farklılık gösterip göstermediğinin tespit edilmesi için Mann Whitney U- testi ve Kruskal Wallis H-testi uygulanmıştır. Sosyal medyayı kullanan genç kuşak bireylerinin bağımlılık düzeylerinin ne yönde olduğunun araştırmaya katılanların cinsiyet değişkenlerine göre farklılık gösterip göstermediği test edilmiştir. 
Tablo 9: Internet/Sosyal Medya Bağımlılık Ölçeğinin Kontrol Kaybı-

Online Kalma ve Sosyal İlișki Boyutlarının Cinsiyet Değișkeni ile İlişsisi

\begin{tabular}{|l|r|r|r|r|}
\hline & kontrol_kaybi & online_kalma & \multicolumn{1}{c|}{ sosyal_ilișki } & \multicolumn{1}{c|}{ toplam } \\
\hline Mann-Whitney U & 20227,500 & 20927,000 & 21112,000 & 22250,000 \\
Wilcoxon W & 38563,500 & 39263,000 & 51247,000 & 40586,000 \\
Z & $-2,432$ & $-1,897$ & $-1,776$ &,- 879 \\
Asymp. Sig. (2-tailed) &, 015 &, 058 &, 076 &, 379 \\
\hline
\end{tabular}

Tablo 9 incelendiğinde, ölçeğin online kalma ve sosyal ilişki boyutunun sigma değerinin 0,05 'ten büyük olduğu görülmektedir. Sosyal medyayı kullanan genç kuşak bireylerinin bağımlılık düzeylerinin online kalma ve sosyal ilişki algısı cinsiyet değişkeni açısından anlamlı bir farklılık göstermemektedir. Ancak ölçeğin kontrol kaybı boyutunda sigma değerinin 0,05 'in altında olduğu ortaya koyulmuştur. Bu veri neticesinde ölçeğin kontrol kaybı boyutu cinsiyet değişkeni açısından anlamlı bir farklılık göstermektedir. Kontrol kaybı boyutunun ortalamalarını ele aldığımızda 17,93 mean (ortalama) değeriyle kadın katılımcıların kontrol kaybı düzeylerinin 16,24 mean değeriyle erkek katılımcılara göre daha yüksek olduğu söylenebilir.

Tablo 10: Internet/Sosyal Medya Bağımlılık Ölçeğinin Kontrol Kaybı-

Online Kalma ve Sosyal İlişsi Boyutlarının Yaş Değişkeni ile İlişsisi

\begin{tabular}{|l|r|r|r|r|}
\hline & kontrol_kaybi & online_kalma & sosyal_ilişki & toplam \\
\hline Chi-Square & 5,787 &, 880 &, 510 & 2,480 \\
df & 3 & 3 & 3 & 3 \\
Asymp. Sig. &, 122 &, 830 &, 917 &, 479 \\
\hline
\end{tabular}

Tablo 10 incelendiğinde, ölçeğin kontrol kaybı, online kalma ve sosyal ilişki boyutunun sigma değerinin 0,05 'ten büyük olduğu görülmektedir. Sosyal medyayı kullanan genç kuşak bireylerinin bağımlılık durumlarının kontrol kaybı, online kalma ve sosyal ilişki düzeyleri yaş değişkeni açısından anlamlı bir farklılık göstermemektedir.

Tablo 11: Internet/Sosyal Medya Bağımlılık Ölçeğinin Kontrol Kaybı-Online Kalma ve Sosyal İlişski Boyutlarının Öğretim Türü Değișkeni ile İlişkisi

\begin{tabular}{|l|r|r|r|r|}
\hline & kontrol_kaybi & online_kalma & \multicolumn{1}{c|}{ sosyal_ilișki } & \multicolumn{1}{c|}{ toplam } \\
\hline Mann-Whitney U & 18807,500 & 18986,500 & 19166,000 & 18420,000 \\
Wilcoxon W & 61585,500 & 61764,500 & 61944,000 & 61198,000 \\
Z & $-1,794$ & $-1,651$ & $-1,523$ & $-2,105$ \\
Asymp. Sig. (2-tailed) &, 073 &, 099 &, 128 &, 035 \\
\hline
\end{tabular}

Tablo 11 incelendiğinde, ölçeğin kontrol kaybı, online kalma ve sosyal ilişki boyutunun sigma değerinin 0,05 'ten büyük olduğu görülmektedir. Sosyal medyayı kullanan genç kuşak bireylerinin bağımlılık durumlarının kontrol kaybı, online kalma ve sosyal ilişki düzeyleri öğretim türü değişkeni açısından anlamlı bir farklılık göstermemektedir. 
Tablo 12: Internet/Sosyal Medya Bağımlılık Ölçeğinin Kontrol KaybıOnline Kalma ve Sosyal İliş̧ki Boyutlarının Sınıf Değişkeni ile İlişsisi

\begin{tabular}{|l|r|r|r|r|}
\hline & kontrol_kaybi & online_kalma & sosyal_ilişki & toplam \\
\hline Chi-Square & 9,401 & 3,073 & 3,142 & 4,811 \\
df & 4 & 4 & 4 & 4 \\
Asymp. Sig. &, 052 &, 546 &, 534 &, 307 \\
\hline
\end{tabular}

Tablo 12 incelendiğinde, ölçeğin kontrol kaybı, online kalma ve sosyal ilişki boyutunun sigma değerinin 0,05'ten büyük olduğu görülmektedir. Sosyal medyayı kullanan genç kuşak bireylerinin bağımlılık durumlarının kontrol kaybı, online kalma ve sosyal ilişki düzeyleri sınıf değişkeni açısından anlamlı bir farklılık göstermemektedir.

Tablo 13: İnternet/Sosyal Medya Bağımlılık Ölçeğinin Kontrol KaybıOnline Kalma ve Sosyal İliş̧ki Boyutlarının Gelir Değişkeni ile İliş̧kisi

\begin{tabular}{|l|r|r|r|r|}
\hline & kontrol_kaybi & online_kalma & sosyal_ilişki & toplam \\
\hline Chi-Square & 1,499 &, 877 & 2,001 &, 509 \\
df & 2 & 2 & 2 & 2 \\
Asymp. Sig. &, 473 &, 645 &, 368 &, 775 \\
\hline
\end{tabular}

Tablo 13 incelendiğinde, ölçeğin kontrol kaybı, online kalma ve sosyal ilişki boyutunun sigma değerinin 0,05 'ten büyük olduğu görülmektedir. Sosyal medyayı kullanan genç kuşak bireylerinin bağımlılık durumlarının kontrol kaybı, online kalma ve sosyal ilişki düzeyleri gelir değişkeni açısından anlamlı bir farklılık göstermemektedir.

Tablo 14: İnternet/Sosyal Medya Bağımlılık Ölçeğinin Kontrol Kaybı-Online Kalma ve Sosyal İlişki Boyutlarının Sosyal Medyaya Girilen Ortam Değişkeni ile İlişskisi

\begin{tabular}{|l|r|r|r|r|}
\hline & kontrol_kaybi & online_kalma & sosyal_ilişki & toplam \\
\hline Chi-Square & 4,840 & 1,611 & 3,063 & 4,017 \\
df & 2 & 2 & 2 & 2 \\
Asymp. Sig. &, 089 &, 447 &, 216 &, 134 \\
\hline
\end{tabular}

Tablo 14 incelendiğinde, ölçeğin kontrol kaybı, online kalma ve sosyal ilişki boyutunun sigma değerinin 0,05 'ten büyük olduğu görülmektedir. Sosyal medyayı kullanan genç kuşak bireylerinin bağımlılık durumlarının kontrol kaybı, online kalma ve sosyal ilişki düzeyleri sosyal medyaya girilen ortam değişkeni açısından anlamlı bir farklılık göstermemektedir.

Tablo 15: Internet/Sosyal Medya Bağımlılık Ölçeğinin Kontrol Kaybı-Online Kalma ve Sosyal İliş̧ki Boyutlarının Sosyal Medyada AktifOlunan Süre Değişkeni ile İlişkisi

\begin{tabular}{|l|r|r|r|r|}
\hline & kontrol_kaybi & online_kalma & sosyal_ilişki & \multicolumn{1}{c|}{ toplam } \\
\hline Chi-Square & 90,268 & 96,226 & 47,533 & 96,733 \\
df & 4 & 4 & 4 & 4 \\
Asymp. Sig. &, 000 &, 000 &, 000 &, 000 \\
\hline
\end{tabular}


Tablo 15 incelendiğinde, kontrol kaybı, ölçeğin online kalma ve sosyal ilişki boyutunun sigma değerinin 0,05 'ten küçük olduğu görülmektedir. Sosyal medyayı kullanan genç kuşak bireylerinin bağımlılık düzeylerinin kontrol kaybı, online kalma ve sosyal ilişki algısı sosyal medyada aktif olunan süre değişkeni açısından anlamlı bir farklılık göstermektedir.

Tablo 16: Internet/Sosyal Medya Bağımlılık Ölçeğinin Kontrol KaybıOnline Kalma ve Sosyal İlişki Boyutlarının Sosyal Medyada Aktif

Olunan Süre (1 Saatten Daha Az ve 1-3 Saat Arası) ile İlişkisi

\begin{tabular}{|l|r|r|r|r|}
\hline & kontrol_kaybi & online_kalma & \multicolumn{1}{c|}{ sosyal_ilişki } & \multicolumn{1}{c|}{ toplam } \\
\hline Mann-Whitney U & 3706,000 & 3648,000 & 4412,000 & 3308,500 \\
Wilcoxon W & 5917,000 & 5859,000 & 6623,000 & 5519,500 \\
Z & $-5,712$ & $-5,824$ & $-4,568$ & $-6,406$ \\
Asymp. Sig. (2-tailed) &, 000 &, 000 &, 000 &, 000 \\
\hline
\end{tabular}

Tablo 16 incelendiğinde, kontrol kaybı, ölçeğin online kalma ve sosyal ilişki boyutunun sigma değerinin 0,05 'ten küçük olduğu görülmektedir. Sosyal medyayı kullanan genç kuşak bireylerinin bağımlılık düzeylerinin kontrol kaybı, online kalma ve sosyal ilişki algısı sosyal medyada aktif olunan (1 saatten daha az) ve (1-3 saat arası) süre değişkeni açısından anlamlı bir farklılık göstermektedir. Bu bağlamda katılımcıların (1 saatten daha az) sosyal medya kullanımı ile (1-3 saat arası) sosyal medya kullanımı bağımlılık düzeyini etkiler niteliktedir.

Tablo 17: İnternet/Sosyal Medya Bağımlılık Ölçeğinin Kontrol Kaybı - Online Kalma ve Sosyal İlişki Boyutlarının Sosyal Medyada AktifOlunan Süre (1 Saatten Daha Az ve 4-6 Saat Arası) ile İlişkisi

\begin{tabular}{|l|r|r|r|r|}
\hline & kontrol_kaybi & online_kalma & \multicolumn{1}{c|}{ sosyal_ilișki } & \multicolumn{1}{c|}{ toplam } \\
\hline Mann-Whitney U & 1355,000 & 1253,500 & 1861,500 & 1151,500 \\
Wilcoxon W & 3566,000 & 3464,500 & 4072,500 & 3362,500 \\
Z & $-7,469$ & $-7,772$ & $-6,132$ & $-8,036$ \\
Asymp. Sig. (2-tailed) &, 000 &, 000 &, 000 &, 000 \\
\hline
\end{tabular}

Tablo 17 incelendiğinde, kontrol kaybı, ölçeğin online kalma ve sosyal ilişki boyutunun sigma değerinin 0,05'ten küçük olduğu görülmektedir. Sosyal medyayı kullanan genç kuşak bireylerinin bağımlılık düzeylerinin kontrol kaybı, online kalma ve sosyal ilişki algısı sosyal medyada aktif olunan (1 saatten daha az) ve (4-6 saat arası) süre değişkeni açısından anlamlı bir farklılık göstermektedir. Bu bağlamda katılımcıların (1 saatten daha az) sosyal medya kullanımı ile (4-6 saat arası) sosyal medya kullanımı bağımlılık düzeyini etkiler niteliktedir.

Tablo 18: Internet/Sosyal Medya Bağımlılık Ölçeğinin Kontrol KaybıOnline Kalma ve Sosyal İlişki Boyutlarının Sosyal Medyada Aktif Olunan Süre (1 Saatten Daha Az ve 7 Saat ve Üzeri) ile İlişkisi

\begin{tabular}{|l|r|r|r|r|}
\hline & kontrol_kaybi & online_kalma & \multicolumn{1}{c|}{ sosyal_ilișki } & \multicolumn{1}{c|}{ toplam } \\
\hline Mann-Whitney U & 267,500 & 217,500 & 476,000 & 260,500 \\
Wilcoxon W & 2478,500 & 2428,500 & 2687,000 & 2471,500 \\
Z & $-6,234$ & $-6,638$ & $-4,921$ & $-6,277$ \\
Asymp. Sig. (2-tailed) &, 000 &, 000 &, 000 &, 000 \\
\hline
\end{tabular}


Tablo 18 incelendiğinde, kontrol kaybı, ölçeğin online kalma ve sosyal ilişki boyutunun sigma değerinin 0,05'ten küçük olduğu görülmektedir. Sosyal medyayı kullanan genç kuşak bireylerinin bağımlılık düzeylerinin kontrol kaybı, online kalma ve sosyal ilişki algısı sosyal medyada aktif olunan (1 saatten daha az) ve (7 saat ve üzeri) süre değişkeni açısından anlamlı bir farklılık göstermektedir. Bu bağlamda katılımcıların (1 saatten daha az) sosyal medya kullanımı ile (7 saat ve üzeri) sosyal medya kullanımı bağımlılık düzeyini etkiler niteliktedir.

Tablo 19: Internet/Sosyal Medya Bağımlılık Ölçeğinin Kontrol Kaybı-Online Kalma ve Sosyal İlisski Boyutlarının Sosyal Medyada Aktif Olunan Süre (1 Saatten Daha Az ve Diğer) ile ilisșkisi

\begin{tabular}{|l|r|r|r|r|}
\hline & kontrol_kaybi & online_kalma & sosyal_ilişki & \multicolumn{1}{c|}{ toplam } \\
\hline Mann-Whitney U & 131,500 & 155,000 & 142,000 & 148,000 \\
Wilcoxon W & 2342,500 & 2366,000 & 157,000 & 2359,000 \\
Z &,- 758 &,- 231 &,- 587 &,- 384 \\
Asymp. Sig. (2-tailed) &, 448 &, 817 &, 557 &, 701 \\
Exact Sig. [2*(1-tailed &, $463^{\text {b }}$ &, $836^{\text {b }}$ &, $623^{\text {b }}$ &, $719^{\text {b }}$ \\
Sig.)] & & & & \\
\hline
\end{tabular}

Tablo 19 incelendiğinde, kontrol kaybı, ölçeğin online kalma ve sosyal ilişki boyutunun sigma değerinin 0,05 'ten büyük olduğu görülmektedir. Sosyal medyayı kullanan genç kuşak bireylerinin bağımlılık düzeylerinin kontrol kaybı, online kalma ve sosyal ilişki algısı sosyal medyada aktif olunan (1 saatten daha az) ve diğer süre değişkeni açısından anlamlı bir farklılık göstermemektedir. Bu bağlamda katılımcıların (1 saatten daha az) sosyal medya kullanımı ile diğer süre değişkeni sosyal medya kullanımı bağımlılık düzeyini etkilememektedir.

Tablo 20: Internet/Sosyal Medya Bağımlılık Ölçeğinin Kontrol Kaybı-Online Kalma ve Sosyal İlişki Boyutlarının Sosyal Medyada Aktif Olunan Süre (1-3 Saat ve 4-6 Saat Arası) ile İlișkisi

\begin{tabular}{|l|r|r|r|r|}
\hline & kontrol_kaybi & online_kalma & sosyal_iliş,ki & \multicolumn{1}{c|}{ toplam } \\
\hline Mann-Whitney U & 8480,500 & 8498,000 & 10220,000 & 8460,000 \\
Wilcoxon W & 30635,500 & 30653,000 & 32375,000 & 30615,000 \\
Z & $-5,049$ & $-5,033$ & $-2,991$ & $-5,065$ \\
Asymp. Sig. (2-tailed) &, 000 &, 000 &, 003 &, 000 \\
\hline
\end{tabular}

Tablo 20 incelendiğinde, kontrol kaybı, ölçeğin online kalma ve sosyal ilişki boyutunun sigma değerinin 0,05 'ten küçük olduğu görülmektedir. Sosyal medyayı kullanan genç kuşak bireylerinin bağımlılık düzeylerinin kontrol kaybı, online kalma ve sosyal ilişki algısı sosyal medyada aktif olunan (1-3 saat) ve (4-6 saat arası) süre değişkeni açısından anlamlı bir farklılık göstermektedir. Bu bağlamda katılımcıların (1-3 saat arası) sosyal medya kullanımı ile (4-6 saat arası) sosyal medya kullanımı bağımlılık düzeyini etkiler niteliktedir.

Tablo 21: Internet/Sosyal Medya Bağımlılık Ölçeğinin Kontrol Kaybı-Online Kalma ve Sosyal İlişsi Boyutlarının Sosyal Medyada Aktif Olunan Süre (1-3 Saat ve 7 Saat ve Üzeri) ile İlișkisi

\begin{tabular}{|l|r|r|r|r|}
\hline & kontrol_kaybi & online_kalma & \multicolumn{1}{c|}{ sosyal_ilișki } & \multicolumn{1}{c|}{ toplam } \\
\hline Mann-Whitney U & 1612,500 & 1526,500 & 2597,000 & 1777,500 \\
Wilcoxon W & 23767,500 & 23681,500 & 24752,000 & 23932,500 \\
Z & $-5,137$ & $-5,368$ & $-2,578$ & $-4,697$ \\
Asymp. Sig. (2-tailed) &, 000 &, 000 &, 010 &, 000 \\
\hline
\end{tabular}


Tablo 21 incelendiğinde, ölçeğin kontrol kaybı, online kalma ve sosyal ilişki boyutunun sigma değerinin 0,05 'ten küçük olduğu görülmektedir. Sosyal medyayı kullanan genç kuşak bireylerinin bağımlılık düzeylerinin kontrol kaybı, online kalma ve sosyal ilişki algısı sosyal medyada aktif olunan (1-3 saat) ve (7 saat ve üzeri) süre değişkeni açısından anlamlı bir farklılık göstermektedir. Bu bağlamda katılımcıların (1-3 saat arası) sosyal medya kullanımı ile (7 saat ve üzeri) sosyal medya kullanımı bağımlılık düzeyini etkiler niteliktedir.

Tablo 22: Internet/Sosyal Medya Bağımlılık Ölçeğinin Kontrol Kaybı-Online Kalma ve Sosyal İlișki Boyutlarının Sosyal Medyada Aktif Olunan Süre (1-3 Saat ve Diğer) ile İlișkisi

\begin{tabular}{|l|r|r|r|r|}
\hline & kontrol_kaybi & online_kalma & \multicolumn{1}{c|}{ sosyal_ilișki } & \multicolumn{1}{c|}{ toplam } \\
\hline Mann-Whitney U & 453,000 & 391,000 & 320,000 & 392,500 \\
Wilcoxon W & 468,000 & 406,000 & 335,000 & 407,500 \\
Z &,- 525 &,- 978 & $-1,514$ &,- 964 \\
Asymp. Sig. (2-tailed) &, 600 &, 328 &, 130 &, 335 \\
\hline
\end{tabular}

Tablo 22 incelendiğinde, kontrol kaybı, ölçeğin online kalma ve sosyal ilişki boyutunun sigma değerinin 0,05’ten büyük olduğu görülmektedir. Sosyal medyayı kullanan genç kuşak bireylerinin bağımlılık düzeylerinin kontrol kaybı, online kalma ve sosyal ilişki algısı sosyal medyada aktif olunan (1-3 saat arası) ve diğer süre değişkeni açısından anlamlı bir farklılık göstermemektedir. Bu bağlamda katılımcıların (1-3 saat arası) sosyal medya kullanımı ile diğer süre değişkeni sosyal medya kullanımı bağımlılık düzeyini etkilememektedir.

Tablo 23: Internet/Sosyal Medya Bağımlılık Ölçeğinin Kontrol Kaybı-Online Kalma ve Sosyal İlișki Boyutlarının Sosyal Medyada Aktif Olunan Süre (4-6 Saat ve 7 Saat ve Üzeri) ile İlișkisi

\begin{tabular}{|l|r|r|r|r|}
\hline & kontrol_kaybi & online_kalma & \multicolumn{1}{c|}{ sosyal_ilişki } & \multicolumn{1}{c|}{ toplam } \\
\hline Mann-Whitney U & 1368,500 & 1374,000 & 1870,000 & 1489,000 \\
Wilcoxon W & 8749,500 & 8755,000 & 9251,000 & 8870,000 \\
Z & $-2,983$ & $-2,965$ &,- 812 & $-2,457$ \\
Asymp. Sig. (2-tailed) &, 003 &, 003 &, 417 &, 014 \\
\hline
\end{tabular}

Tablo 23 incelendiğinde, ölçeğin kontrol kaybı ve online kalma boyutunun sigma değerinin 0,05'ten küçük olduğu görülmektedir. Ancak ölçeğin sosyal ilişki boyutunun sigma değerinin 0,05 'ten büyük olduğu görülmektedir. Sosyal medyayı kullanan genç kuşak bireylerinin bağımlılık düzeylerinin kontrol kaybı ve online kalma algısı sosyal medyada aktif olunan (4-6 saat) ve ( 7 saat ve üzeri) süre değişkeni açısından anlamlı bir farklılık göstermektedir. Ölçeğin sosyal ilişki algısı sosyal medyada aktif olunan (4-6 saat ) ve (7 saat ve üzeri) süre değişkeni açısından anlamlı bir farklılık göstermemektedir.

Tablo 24: Internet/Sosyal Medya Bağımlılık Ölçeğinin Kontrol Kaybı-Online Kalma ve Sosyal İlişsi Boyutlarının Sosyal Medyada Aktif Olunan Süre (4-6 Saat ve / Diğer) ile İlişskisi

\begin{tabular}{|l|r|r|r|r|}
\hline & kontrol_kaybi & online_kalma & \multicolumn{1}{c|}{ sosyal_ilișki } & \multicolumn{1}{c|}{ toplam } \\
\hline Mann-Whitney U & 216,000 & 181,500 & 153,500 & 184,500 \\
Wilcoxon W & 231,000 & 196,500 & 168,500 & 199,500 \\
Z & $-1,083$ & $-1,518$ & $-1,872$ & $-1,475$ \\
Asymp. Sig. (2-tailed) &, 279 &, 129 &, 061 &, 140 \\
\hline
\end{tabular}


Tablo 24 incelendiğinde, kontrol kaybı, ölçeğin online kalma ve sosyal ilişki boyutunun sigma değerinin 0,05'ten büyük olduğu görülmektedir. Sosyal medyayı kullanan genç kuşak bireylerinin bağımlılık düzeylerinin kontrol kaybı, online kalma ve sosyal ilişki algısı sosyal medyada aktif olunan (4-6 saat arası) ve diğer süre değişkeni açısından anlamlı bir farklılık göstermemektedir. Bu bağlamda katılımcıların (4-6 saat arası) sosyal medya kullanımı ile diğer süre değişkeni sosyal medya kullanımı bağımlılık düzeyini etkilememektedir.

Tablo 25: Internet/Sosyal Medya Bağımlılık Ölçeğinin Kontrol Kaybı-Online Kalma ve Sosyal İlişsi Boyutlarının Sosyal Medyada Aktif Olunan Süre (7 Saat ve Üzeri / Diğer) ile İlișkisi

\begin{tabular}{|l|r|r|r|r|}
\hline & kontrol_kaybi & online_kalma & sosyal_ilişki & toplam \\
\hline Mann-Whitney U & 42,500 & 35,500 & 41,000 & 39,500 \\
Wilcoxon W & 57,500 & 50,500 & 56,000 & 54,500 \\
Z & $-1,789$ & $-2,089$ & $-1,863$ & $-1,914$ \\
Asymp. Sig. (2-tailed) &, 074 &, 037 &, 062 &, 056 \\
Exact Sig. [2*(1-tailed &, $074^{\mathrm{b}}$ &, $035^{\mathrm{b}}$ &, $067^{\mathrm{b}}$ &, $054^{\mathrm{b}}$ \\
Sig.)] & & & \\
\hline
\end{tabular}

Tablo 25 incelendiğinde, ölçeğin kontrol kaybı ve sosyal ilişki boyutunun sigma değerinin 0,05 'ten büyük olduğu görülmektedir. Ancak ölçeğin online kalma boyutunun sigma değerinin 0,05 'ten küçük olduğu görülmektedir. Sosyal medyayı kullanan genç kuşak bireylerinin bağımlılık düzeylerinin kontrol kaybı ve sosyal ilişki algısı sosyal medyada aktif olunan (7 saat ve üzeri) ve diğer süre değişkeni açısından anlamlı bir farklılık göstermemektedir. Ölçeğin sosyal online kalma algısı sosyal medyada aktif olunan (7 saat ve üzeri) ve diğer süre değişkeni açısından anlamlı bir farklılık göstermektedir. Bu bağlamda online kalma boyutu doğrultusunda katılımcıların (7 saat ve üzeri) sosyal medya kullanımı ve diğer süre değişkeni sosyal medya kullanımı bağımlılık düzeyini etkilemektedir.

Tablo 26: İnternet/Sosyal Medya Bağımlılık Ölçeğinin Kontrol Kaybı-Online Kalma ve Sosyal İlişki Boyutlarının Sosyal Medyayı Ne Kadar Yıldır Kullanımı Değişkeni ile İlişskisi

\begin{tabular}{|l|r|r|r|r|}
\hline & kontrol_kaybi & online_kalma & sosyal_ilişki & toplam \\
\hline Chi-Square & 12,980 & 9,071 & 5,417 & 10,413 \\
df & 4 & 4 & 4 & 4 \\
Asymp. Sig. &, 114 &, 059 &, 247 &, 340 \\
\hline
\end{tabular}

Tablo 26 incelendiğinde, ölçeğin kontrol kaybı, online kalma ve sosyal ilişki boyutunun sigma değerinin 0,05 'ten büyük olduğu görülmektedir. Sosyal medyayı kullanan genç kuşak bireylerinin bağımlılık durumlarının kontrol kaybı, online kalma ve sosyal ilișki düzeyleri sosyal medyanın ne kadar yıldır kullanıldığı değişkeni açısından anlamlı bir farklılık göstermemektedir.

\section{Sonuç ve Öneriler}

Bu çalıșmada Ege Üniversitesi İletişim Fakültesi Halkla İlişkiler ve Tanıtım Bölümü lisans ve lisansüstü öğrencilerinin sosyal medya kullanım alışkanlıkları ile sosyal medya bağımlılık düzeylerini ölçmeye yönelik sorular ve hipotezler ortaya konulmuştur. Söz konusu öğrenciler üzerinde gerçekleştirilen anket çalışması, "Sosyal Medya Bağımlılık" düzeyleri ile ilgili tutum ve davranışlarını ölçen 19 sorudan 
oluşmaktadır. Öğrencilerin sosyal medya kullanım durumları toplamda 3 soru ile ölçümlenmiștir. Diğer sorular demografik özellikleri ortaya koymaya yöneliktir. Bu araștırma doğrultusunda öğrencilere ilgili anket soruları kağıt üzerinden dağıtılarak uygulanmış ve toplam 498 öğrenciye ulaşılarak, 436 işaretlenmiş anket verisi elde edilmiştir. Anket, bilgisayar ortamında SPSS programı kullanılarak ve bu programın frekans ve reliability güvenilirlik, NPar tests, Mann-Whitney testi ile Kruskal-Wallis test kullanılarak değerlendirilmiștir. Bu analizler sonucunda Ege Üniversitesi İletişim Fakültesi Halkla İlişkiler ve Tanıtım Bölümü lisans ve lisansüstü öğrencilerden elde edilen bulgulara ilişkin sonuçlar şunlardır:

- Anket katılımcılarının çoğu kadınlardan oluşmaktadır (\% 56.2).

- (22-25) yaş grubunda yer alan öğrenciler çoğunluğu oluşturmaktadır (\% 48.2).

- Katılımcıların büyük bir oranı birinci öğretimde yer almaktadır (\% 67.0).

- 3. Sınıf öğrenciler büyük çoğunluğu oluşturmaktadır (\% 30.7).

- Katılımcıların büyük çoğunluğu (501-1000tl arası) gelir seviyesine sahip olanların oranı \% 44.5'dir.

- Sosyal medya kullanan öğrencilerden \% 90.4'ü ev ya da yurttan bağlanmaktadır.

- Gençlerin sosyal medyada aktif oldukları süre \% 48.2 ile (1-3 saat) tir.

- Katılımcıların \% 46.6 ile büyük bir çoğunluğu 7 yıldan daha fazla sosyal medyayı kullanmaktadırlar.

Araştırmanın hipotezleri şu şekildedir:

- Sosyal medya bağımlılığı ile cinsiyet arasında sadece kontrol kaybı boyutunda anlamlı bir ilişki vardır. Bu farklılığın da kadın katılımcıların kontrol kaybı düzeylerinin erkek katılımcılara göre daha yüksek olmasından kaynaklandığı söylenebilir (Hipotez 1).

- Sosyal medya bağımlılığı ile yaş grupları arasında anlamlı bir ilişki yoktur (Hipotez 2).

- Sosyal medya bağımlılığı ile öğretim türü arasında anlamlı bir ilişki yoktur (Hipotez 3).

- Sosyal medya bağımlılığı ile sınıf arasında anlamlı bir ilişki yoktur (Hipotez 4).

- Sosyal medya bağımlılığı ile gelir arasında anlamlı bir ilişki yoktur (Hipotez 5).

- Sosyal medya bağımlılığı ile sosyal medyaya girilen ortam arasında anlamlı bir ilişki yoktur (Hipotez 6).

- Sosyal medya bağımlılığı ile sosyal medyada aktif olunan süre arasında anlamlı bir ilişki vardır. Bu ilişkinin ölçeğin her boyutunda (1,2), (1, 3), (1, 4), (2, 3), (2, $4),(2,5)$ ve $(3,4)$ arasında olduğu görülmektedir. Bu durum sosyal medyada aktif olunan süre arttıkça sosyal medyaya bağımlılık puanlarının arttığı şeklinde yorumlanabilir (Hipotez 7).

- Araștırmada sosyal medya bağımlılığı ile sosyal medya kullanım süresi arasında anlamlı bir ilişki bulunmamıştır (Hipotez 8).

Sonuç olarak, araştırma hipotezlerinden sadece 1. ve 7. Hipotezlerde anlamlı bir ilişki ortaya konulmuştur. Diğer hipotezler arasında anlamlı bir ilişki belirlenmemiştir. Bu durum sosyal medya bağımlılığının kız öğrencilerin kontrol kaybı erkek öğrencilere göre daha yüksek olduğu yönündedir. Buna ilaveten, gençlerin sosyal medyada aktif oldukları süre arttıkça sosyal medya bağımlılık puanlarının arttığı görülmektedir.

Özellikle son yıllarda sosyal medyaya erişim zaman ve mekan sınırlaması olmadan mobilolarak da gerçekleştirebildiği için izlenmesi daha kolay olmaktadır. Bilgi iletişim 
teknolojileri içerisinde doğan y kuşağı gençliği olarak üniversite öğrencileri de eğitim, eğlence gibi farklı amaçlarla sosyal medyanın aktif kullanıcıları ve üreticileridir. Sosyal medyanın aktif kullanıcıları sosyal ağlardaki çeşitli paylaşımlarıyla iletişim sürecine dahil olarak kendilerini gerçekleştirebilmekte, özgüvenlerini arttırabilmekte ve bireysel haz ve doyuma ulaşabilmektedirler. Günlük yaşamın rutini haline gelen sosyal medya internet ve mobil kullanımlarla zaman ve mekan sınırlarını ortadan kaldırarak istenilen yer ve süreçte ortama bağlanabilmektedir.

Son yıllarda yapılan araştırmalar göstermiștir ki; sosyal medya kullanımları bağımlılık sınırlarını zorlamaktadır. Her ne kadar birey kendini bağımlı olarak nitelendirmese de sosyal medyayı kullanma süreleri saat bakımından (1-3 saat) kullananlara göre (4-6 saat) ile (7 saat ve üzerinde) sosyal medya kullanım bağımlılık düzeylerini etkilemektedir. Bu etkileme kontrol kaybı, online kalma ve sosyal ilişki boyutları bakımından değişimler gösterebilmektedir. Özellikle kız öğrencilerin erkek öğrencilere oranla sosyal medyayı görsel açıdan paylaşımlarla ve sosyal açıdan iletişim boyutunda daha etkin kullandığı düşünüldügünde sosyal medya bağımlılığının kontrol kaybı boyutunda bir takım sorunlar yaşayabilmektedirler.

Tüm bu elde edilen bulgular neticesinde özellikle sosyal medyayı bağımlılık derecesinde kullanan Y gençliğine yönelik öneriler aşağıda yer almaktadır:

- Gençlerin, kendilerini gerçekleștirebilecekleri yeni iletişim ortamlarına girmeleri, hobiler edinmeleri, kişilerarası iletişimi destekleyici kulüplere dahil olmaları özendirilmelidir.

- Bireylerin kendi oto kontrol sistemlerini geliştirici, sosyal medya kullanım sürelerini sınırlamaları ya da günlük yaşamlarında zamanlarını doğru yönetmeyi öğrenmeleri gerekmektedir. Bunun için gerekli durumlarda profesyonel destek almaya istekli olmaları beklenmektedir.

- Ailelerin bu süreçte yer almaları ve çocuklarıyla daha fazla ilgili olmaları önem arz etmektedir.

- Sosyal medya bağımlılığı konusunda bilinç oluşturulmasına yönelik medya ile eğitim kurumlarındaki faaliyetlerin işlevsel hale getirilmesi kaçınılmazdır.

- Sağlık örgütlerince sosyal medya bağımlılığının oluşturduğu olumsuz etkilerin konferans, seminer, panellerle gençlere anlatılmasına imkan tanınması önemlidir. - Y kuşağına ulaşıncaya dek ilköğretim düzeyindeki Z kuşağının öğrenme süreçlerinde sağlıklı sosyal medya konusunda gerekli olan eğitimi almaları ile yeni beceriler kazandırılmalıdır.

- Araştırmayla ilgili olarak başka bir örneklem grubunda çalışmanın yinelenmesi verimliği arttıracaktır.

- Farklı araştırma yöntemleri ile Y kuşağı gençliğinin algılarının ölçümlenmesi ve karşılaştırmalı analizlere gidilerek durum tespiti yapılarak yeni sonuçlara ve değerlendirmelere gidilmesi literatüre katkı sağlayacaktır.

\section{Kaynakça}

Akçay, H. (2011). "Kullanımlar ve Doyumlar Yaklaşımı Bağlamında Sosyal Medya Kullanımı: Gümüşhane Üniversitesi Üzerine Bir Araştırma”, İletişim Kuram ve Araştırma Dergisi, 33, 137-161.

Alioğlu, N. (2015). "Duygusal Tatmin Aracı Olarak Sosyal Medya Kullanımı Üzerine Bir Alan Araştırması", İstanbul Sosyal Bilimler Dergisi, 9/2, 1-27. 
Babacan, M. E. (2015). Sosyal Medya Ve Gençlik. 1. Baskı. İstanbul: Açılım Kitap.

Choudhury, M. D., Gamon, M., Counts, S. \& Horvitz, E. (2013). “Predicting Depression via Social Media", in ICWSM, (p. 2).

Eley, B. ve Tilley, S. (2009). Online Marketing Inside Out, 1. Baskl, Cambridge: Sitepoint.

Griffiths, M. D. (1999). “Internet Addıction: Fact or Fiction?”, The Psyhologist, 12 (5), 246-250.

Hampton, K. N., Goulet, L. S, Rainie, L. \& Purcell, K. (2011). "Social Networking Sites and Our Lives", Pew Research Center's Internet \& American Life Project, Washington (http://pewinternet.org/Reports/2011/Technology---and--social---networks.aspx).

Işık, U. ve Topbaş, H. (2015). "Facebook ve Bağımlılığı Araştırması", The Journal of Academic Social Science Studies, 38, 319-336.

Kuss, D. J. \& Griffiths, M. D. (2011). "On Line Social Networking and Addiction-A Reiew of the Psychological Literature". Internetional Journal of Environmental Research and Public Health, 8(9), 3528-3552.

Kuşay, Y. (2013). Sosyal Medya Ortamında Çekicilik Ve Bağımlılık (Facebook Üzerine Bir Araştırma). Yayın No: 3022, 1. Baskı, İstanbul: Beta Basım A.Ş.

Kuyucu, M. (2014). "Y Kuşağı ve Facebook: Y Kuşağının Facebook Kullanım Alışkanlıkları Üzerine Bir İnceleme". Elektronik Sosyal Bilimler Dergisi, 13, 4950, 55-83.

Özutku, F. ve diğerleri. (2014). Sosyal Medyanın ABC'si. İstanbul: Alfa Yayınları.

Seferoğlu, S. ve Yıldız, H. (2013). “Dijital Çağın Çocukları: İlköğretim Öğrencilerinin Facebook Kullanımları ve İnternet Bağımlıları Üzerine Bir Araştırma”. İletişim ve Diplomasi Dergisi, 2, 31-48.

Sevinç, S. S. (2015). Pazarlama İletişiminde Sosyal Medya. No: 312. İstanbul: Optimist Yayın.

Sutton, J., Palen, L. \& Shklovski, I. (2008). "Backchannels on the Front Lines: Emergent Uses of Social Media in the 2007 Southern California Wildfires", Proceedings of the 5th International ISCRAM Conference - Washington.

Tamar, W. (2009). The New Community Rules: Marketing on the Social Web, (1.Baskı), Sebastopol: O’Reilly Media

Thackeray, R., Neiger , B. L., Hanson , C. L. \& McKenzie, J. F. (2008). "Enhancing Promotional StrategiesWithinSocial Marketing Programs: Use ofWeb 2.0Social Media", Health Promotion Practice (9) 4, DOI: 10.1177/1524839908325335, pp. 338-343.

TUIKK (2017). Yılı Hane Halkı Bilişim Teknolojileri Kullanım Araştırması Sonuçları.

Young, K. S. (1998). "Internet Addiction: The Emergence of a New Clinical Disorder”,. Cyberpsycholoya Behavior. 1 (3). 237-244. 
